\title{
Optimization of Mould Base Production using Ranked Positional Weighted Method and Single Minute Exchange of Die System
}

\author{
Arun A P, Dhamotharan S, Karthikeyan S, Rajini N
}

\begin{abstract}
In the domain of intense global competition, the manufacturers are in need of producing different varieties of products. Successful manufacturing firms in the past have well produced the products based on the minimum amount of requirements in the market. This is so because of customer needs and economy rate is minimum in the past period of time. People like to use molded parts instead of using assembled component in the present days to survey in the market against competitors. So the manufacturer decides to produce a wide variety of mould bases for production and to satisfy the market needs. But the mould base manufacturing is not easier to produce the components to reach the market. It ought to be very much precised and devours more opportunity to produce the component by manufacturer to deliver that in an on-time to market. For this situation, the enterprise which produces distinctive mould bases needs to reduce the lead time is the major fundamental worry of the work. The primary target of this work is to decrease the setup time from 30 minutes to less than 20 minutes for each component. This cannot be accomplished without huge investment and to be versatile for manufacturing different mould parts. This needs special planning to manufacture different moulds. And the result obtained with the help of using Ranked Positional Weighted (RPW) method procedure for an entire operation to calculate the critical path of production of components and also use the Single Minute Exchange Die (SMED) to optimize the setup time in an operation. Results of the research signifies the application of ranking an operation with suitable methodological approach to reduce the cycle time of the production of component to satisfy the market needs.
\end{abstract}

Keyword: RPW Method, Single Minute Exchange Die (SMED), Cycle Time, Lead Time.

\section{INTRODUCTION}

$\mathrm{T}_{\mathrm{h}}$ injection moulding is changing. Plastic part makers are producing increasing varieties of short-run products in all kinds of different sizes, shapes and finish - each requiring a custom-made mould base. In recent years the competition between the industries is more. The industries develop new approaches to survive the world class competition. Now a

Revised Manuscript Received on December 30, 2019.

* Arun A P

Arun A P*, Department of Mechanical Engineering, Kumaraguru College of Technology, Coimbatore, Tamil Nadu, India - 641049.

Dhamotharan S, Department of Mechanical Engineering, Kumaraguru College of Technology, Coimbatore, Tamil Nadu, India - 641049.

Karthikeyan S, Department of Automobile Engineering, Kalasalingam Academy of Research and Education, Virudhunagar, Tamil Nadu, India 626126. Email: skarthikeyan@klu.ac.in

Rajini N, Department of Mechanical Engineering, Kalasalingam Academy of Research and Education, Virudhunagar, Tamil Nadu, India 626126. Email: rajini@klu.ac.in day's customer wants good quality product with less price at one time. The study shows proper utilization can improve the availability of time for the production of products in a proper manner. It improves the Overall Equipment Effectiveness of the company.

By using the ranked positional weighted (RPW) and single minute exchange of die (SMED) concept, we optimize the process from the additional consumption of time and also deliver the products to customer. RPW method is one of line balancing heuristic method which is mainly based on the ranks generated for each operation. SMED is wate reducing process in manufacturing sector and also its one of the lean method. The efficient way to convert the current processing product to next product. The reduction of changeover time is the key concept to reduce the product flow and also to reduce the product processing time and cost.

\section{METHODOLOGY}

\section{A. Ranked Positional Weighted Method}

In this method, the cycle time can be calculated initially and the work station can be allotted accordingly. Line balancing methods are not capable of doing all these things. So in the existing problem of Cashew nut shelling machine RPW method is used.

Steps involved in RPW method-

Step 1: Plot the actual diagram of the manufacturing process

Step 2: Determine position weightage for each component.

Step 3: Working component has to be ranked in the descending order (RPW Value)

Step 4: The highest value product has to be assign initially to the workstation. Next product has to be chosen as per the order. Continue till cycle time is not violated.

Step 5: Repeat step four until all the operations are allotted

\section{B. Layout Modification}

There are many ways an industry can arrange its manufacturing and production facilities. These include both process layout and product layout. These are referred to as hybrid layout, which is the combination of two above mentioned main manufacturing layouts. The process of changing the flow line of job or work piece from one operation to another operation is to be done with the help of proper layout. 
Optimization of Mould Base Production Using Ranked Positional Weighted Method and Single Minute Exchange of Die System

Most of industries are majorly contributed on either process layout or product layout. But some of them are following the combination of both layouts. By this hybrid layout, there must be the reducing of setup time and also material handling and transit time. It is a better use of human resources and easier to control and automate. So, there must be the proper alteration of existing layout to reduce the time and to produce the products in a planned time.

\section{Single Minute Exchange of Die}

From the interpretations and the brainstorming sessions during the data gathering stage, it helped to frame the solution methodologies. So we had a survey related to the designs of the mould bases. The mould bases are the types of dies which are used in plastic injection mouldings, press tools, etc. in our application plastic injection moulding dies are taken into the account.

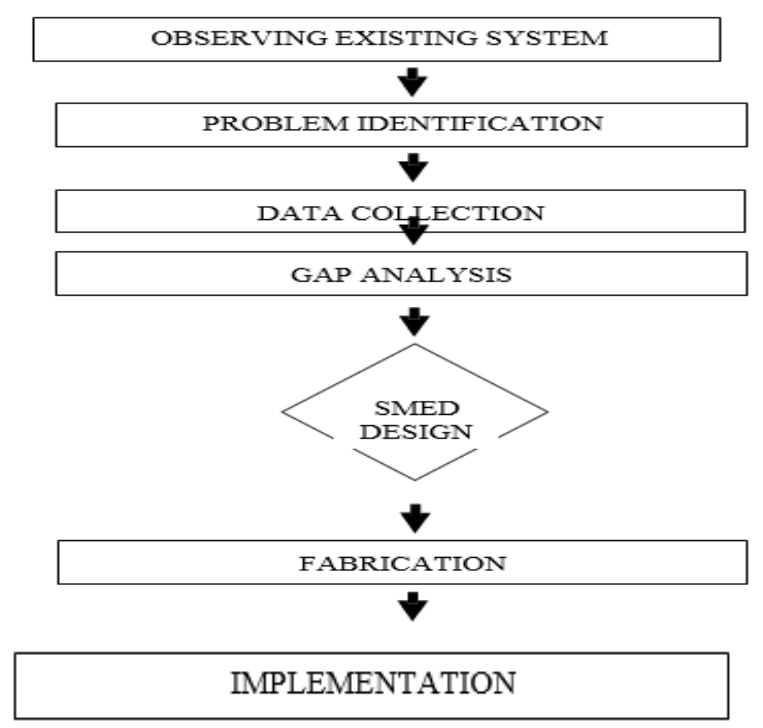

III. CALCULATION

\section{A. Ranked Positional Weighted Method}

Precedence diagram for RPW Calculation are shown below

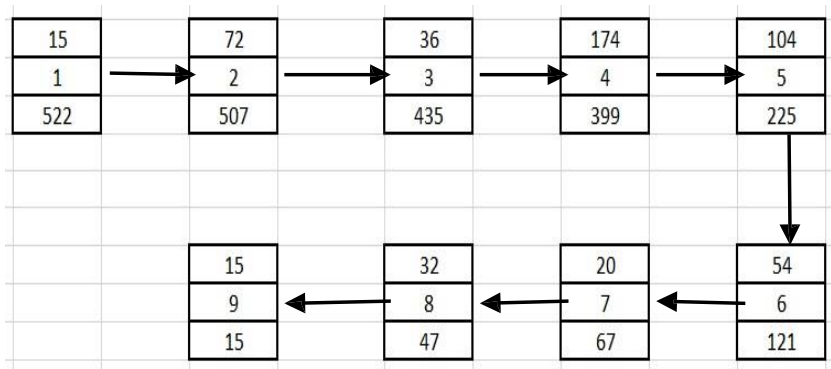

Fig. 1. Precedence Diagram

Total task time (T)

Cycle time(C)

Theoretical no. of work station (N)

$$
\begin{gathered}
=522 \mathrm{~min} \\
=\left(8^{*} 60\right) / 2 \\
=480 / 2 \\
=240 \mathrm{~min} \\
=\mathrm{T} / \mathrm{C} \\
=522 / 240 \\
=2.175
\end{gathered}
$$

The approximated theoretical number of station is 3 Stations.
Table-I: Details of Work Elements \& Precedence

\begin{tabular}{|c|c|c|c|}
\hline ELEMENT & $\begin{array}{c}\text { TIME } \\
(\mathbf{m i n}\end{array}$ & DESCRIPTION & PRECEDORS \\
\hline 1 & 15 & Sizin & - \\
\hline 2 & 72 & Pre-Drilling & 1 \\
\hline 3 & 36 & Radial Drilling & 2 \\
\hline 4 & 174 & Surface Grinding & 3 \\
\hline 5 & 104 & CNC Finishing & 4 \\
\hline 6 & 54 & $\begin{array}{c}\text { Radial Drilling } \\
\text { (Chamfering) }\end{array}$ & 5 \\
\hline 7 & 20 & Deburring & 6 \\
\hline 8 & 32 & Inspection & 7 \\
\hline 9 & 15 & Dispatch & 8 \\
\hline
\end{tabular}

Table-II: Calculate RPW and assign in descending order

\begin{tabular}{|c|c|c|c|}
\hline ELEMENT & $\begin{array}{c}\text { RPW } \\
(\mathbf{m} \boldsymbol{)})\end{array}$ & $\begin{array}{c}\text { TIME } \\
(\mathbf{m i n})\end{array}$ & PRECEDORS \\
\hline 1 & 522 & 15 & - \\
\hline 2 & 507 & 72 & 1 \\
\hline 3 & 435 & 36 & 2 \\
\hline 4 & 399 & 174 & 3 \\
\hline 5 & 225 & 104 & 4 \\
\hline 6 & 121 & 54 & 5 \\
\hline 7 & 67 & 20 & 6 \\
\hline 8 & 47 & 32 & 7 \\
\hline 9 & 15 & 15 & 8 \\
\hline
\end{tabular}

Table-III: Details of Work Stations

\begin{tabular}{|c|c|c|c|}
\hline $\begin{array}{c}\text { STATION } \\
\text { NUMBER }\end{array}$ & LIST & $\begin{array}{c}\text { WORK } \\
\text { ELEMENT } \\
\text { SELECTED }\end{array}$ & $\begin{array}{c}\text { UNASSIGNED } \\
\text { CYCLE TIME } \\
\text { (UACT) }\end{array}$ \\
\hline 1 & - & - & 240 \\
& 1 & 1 & 225 \\
& 1,2 & 2 & 153 \\
& $1,2,3$ & 3 & 117 \\
\hline 2 & - & - & 240 \\
& 4 & 4 & 66 \\
\hline 3 & - & - & 240 \\
& 5 & 5 & 136 \\
& 5,6 & 6 & 82 \\
& $5,6,7$ & 7 & 62 \\
& $5,6,7,8$ & 8 & 30 \\
& $5,6,7,8,9$ & 9 & 15 \\
\hline
\end{tabular}

Balance Efficiency $=\left\{1-\frac{S U A C T}{C T * S N}\right\} * 100$, $=\left\{1-\frac{(117+66+15)}{(240 * 3)}\right\} * 100$

$$
\begin{array}{ll} 
& =(1-0.275) * 100=0.725 * \\
& 100 \\
\text { Balance Efficiency } & =72.5 \% \\
\text { Balance Delay } & =1-\text { Balance Efficiency } \\
& =1-0.725=0.275 \\
\text { Balance Delay } & =27.5 \%
\end{array}
$$

The balance efficiency is used to find the effectiveness of the line and the effectiveness is $72.5 \%$. From the result also find the balance delay of the process line. 


\section{B. Layout Modification}

There must be very essential to maintain the process flow with the minimum consumption of conveyance time to transfer the component from one machine to another machine to complete the process with the help of using $5 \mathrm{~S}$ technique to maintain the workplace clean. In the existing layout, there must be the consumption of more conveyance time to complete the process. The following diagram represents about the existing layout design for the completion of selected product.

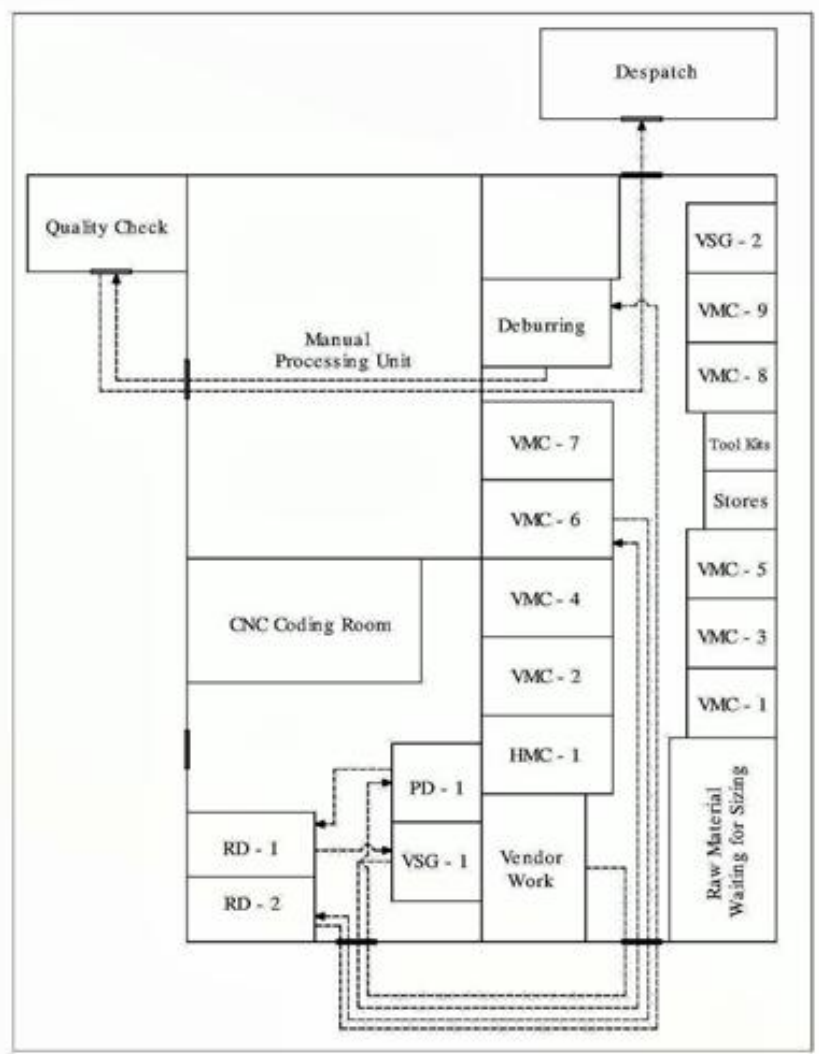

Fig. 2. Existing Layout

There must be used as some important parameters which are expressed in numerical form which are used for table 3.3 and layout are shown as follows

$\begin{array}{ll}\text { Vendor Work } & -1 \\ \text { PD - } 1 & -2 \\ \text { RD - } 1 & -3 \\ \text { VSG - 1 } & -4 \\ \text { VMC - } 6 & -5 \\ \text { RD - } 2 & -6\end{array}$

Deburring -7

Quality Check - $\quad$ -

Despatch $\quad-9$

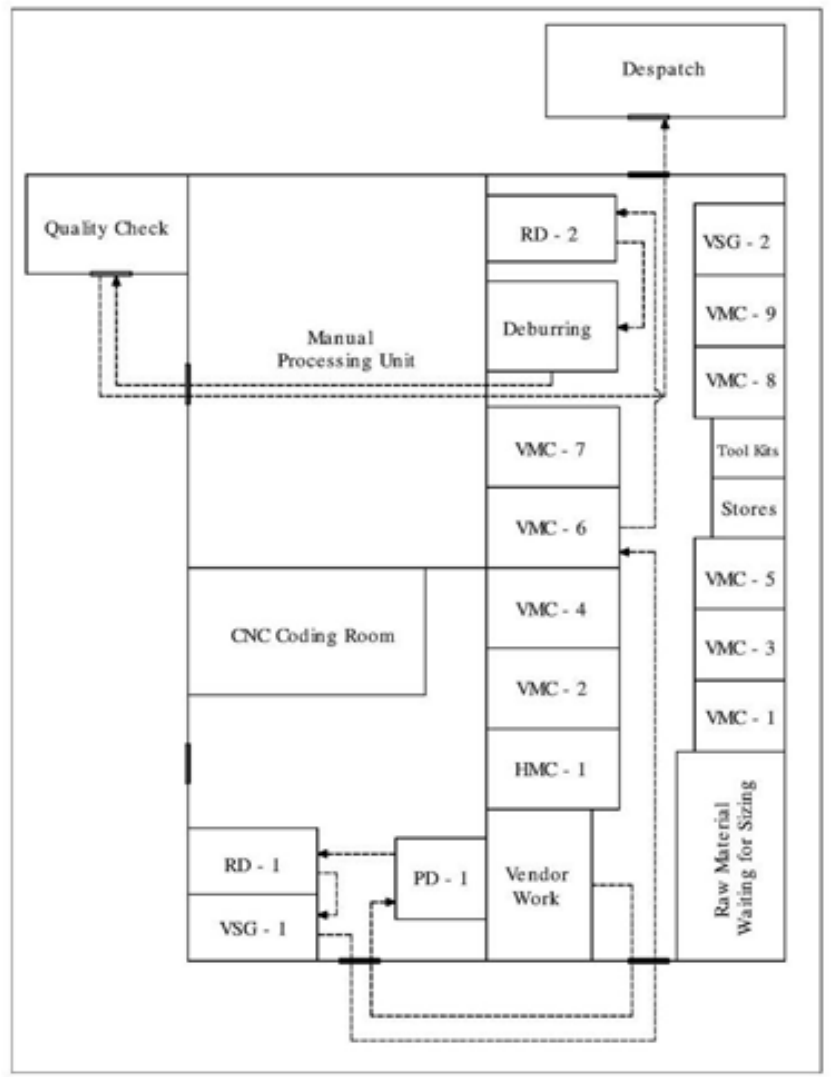

Fig. 3. Suggesting Layout

Table-IV: Existing \& Suggested Layout Flow Time

\begin{tabular}{|c|c|c|}
\hline Process flow & $\begin{array}{c}\text { Existing time } \\
\text { (sec) }\end{array}$ & $\begin{array}{c}\text { Suggested } \\
\text { time } \\
\text { (sec) }\end{array}$ \\
\hline $1-2$ & 50 & 50 \\
\hline $2-3$ & 20 & 20 \\
\hline $3-4$ & 35 & 35 \\
\hline $4-5$ & 80 & 80 \\
\hline $5-6$ & 95 & 15 \\
\hline $6-7$ & 125 & 10 \\
\hline $7-8$ & 65 & 65 \\
\hline $8-9$ & 140 & 140 \\
\hline TOTAL TIME & 605 & 405 \\
\hline
\end{tabular}

In an above diagram, 605 seconds are to be taken as a conveyance time for the production of each product. The suggested layout for the same process have some alteration in alignment of machines and job flow with 405 seconds as conveyance time for each product. When compared with both existing and suggested layout, nearly 200 seconds (i.e, 3:20 minutes) are saved per component. By the continuation of process with these suggested layout flow, there must be results the high productivity and minimum time consumption of production of product. 
Optimization of Mould Base Production Using Ranked Positional Weighted Method and Single Minute Exchange of Die System

\section{Single Minute Exchange of Die}

In additional optimization of time is held in the area of setting the job on the preferred machine. The setup time is to be controlled by altering of some features in an area of holding, clamping, placing and tightening of work piece or job in the machine. There must be taken 5 trails of handling the work piece with machine. The readings are tabulated as follows.

\begin{tabular}{|c|c|c|c|c|c|c|}
\hline \multirow{2}{*}{$\begin{array}{c}\text { Elemen } \\
\mathbf{t}\end{array}$} & \multicolumn{5}{|c|}{ Trail } & \multirow{2}{*}{$\begin{array}{l}\text { Ave } \\
\text { rage } \\
e^{\text {Tim }}\end{array}$} \\
\hline & 1 & 2 & 3 & 4 & 5 & \\
\hline $\begin{array}{l}\text { Unloadi } \\
\text { ng }\end{array}$ & $.75^{2}$ & $.08^{3}$ & $.58^{2}$ & $.77^{2}$ & $.12^{3}$ & 2.86 \\
\hline $\begin{array}{l}\text { Cleanin } \\
\mathrm{g}\end{array}$ & $.06^{1}$ & $.98^{0}$ & $.25^{1}$ & $.22^{1}$ & $.46^{1}$ & 1.19 \\
\hline $\begin{array}{l}\text { Positio } \\
\text { ning } \\
\text { Clamps }\end{array}$ & $.31^{2}$ & $.23^{2}$ & $.48^{2}$ & $.01^{2}$ & $.21^{3}$ & 2.45 \\
\hline $\begin{array}{l}\text { Holding } \\
\text { in } \\
\text { Crane }\end{array}$ & $.14^{1}$ & $.48^{1}$ & $.9^{1}$ & $.62^{1}$ & $.2^{1}$ & 1.47 \\
\hline $\begin{array}{l}\text { Moving } \\
\text { to } \\
\mathrm{m} / \mathrm{c} \\
\text { Table }\end{array}$ & $.42^{3}$ & $.26^{3}$ & $.15^{4}$ & $.98^{3}$ & $.45^{4}$ & 3.85 \\
\hline Placing & $.16^{2}$ & $.28^{2}$ & $.98^{1}$ & $.02^{3}$ & $.59^{2}$ & 2.41 \\
\hline Holding & $.62^{3}$ & $.24^{2}$ & $.1^{3}$ & $.68^{2}$ & $.42^{2}$ & 2.81 \\
\hline $\begin{array}{l}\text { Zero } \\
\text { Setting }\end{array}$ & $.16^{8}$ & $.32^{9}$ & $.2^{6}$ & $.56^{8}$ & $.25^{6}$ & 7.69 \\
\hline $\begin{array}{l}\text { Tighten } \\
\text { ing }\end{array}$ & $.15^{2}$ & $.68^{2}$ & $.49^{2}$ & $.02^{3}$ & $.16^{3}$ & 2.7 \\
\hline $\begin{array}{l}\text { Dry } \\
\text { Run }\end{array}$ & 5 & 5 & 5 & 5 & 5 & 5 \\
\hline
\end{tabular}

The total average time of the setup operation for 5 trails is 32.43 minutes using time study method.

After the time study, Pareto analysis was made to find the potential activities to be focused and prioritized to solve the changeover problem. The calculations were carried out and are shown below in table.

The Pareto analysis shown in figure shows the first three elements itself consumes more time in job changeover (i.e) $51 \%$. The organization has One fourth of the time consumption in changeover is due to zero setting of the job. So it is to be re-engineered with combination of some other elements. Thus it makes the changeover time to reduce efficiently.
Table-VI: Percentage of Contribution

\begin{tabular}{|c|c|c|c|}
\hline $\begin{array}{c}\text { S. } \\
\text { So }\end{array}$ & Elements & $\begin{array}{c}\text { Time } \\
\text { (min) }\end{array}$ & $\begin{array}{c}\text { Cumulati } \\
\text { ve \% of time }\end{array}$ \\
\hline 1 & Zero Setting & 7.69 & $23.71 \%$ \\
\hline 2 & Dry Run & 5 & $39.13 \%$ \\
\hline 3 & $\begin{array}{c}\text { Moving to m/c } \\
\text { table }\end{array}$ & 3.85 & $51.00 \%$ \\
\hline 4 & Unloading & 2.86 & $59.82 \%$ \\
\hline 5 & Holding & 2.81 & $68.49 \%$ \\
\hline 6 & Tightening & 2.7 & $76.81 \%$ \\
\hline 7 & $\begin{array}{l}\text { Positioning } \\
\text { Clamps }\end{array}$ & 2.45 & $84.37 \%$ \\
\hline 8 & Placing & 2.41 & $91.80 \%$ \\
\hline 10 & $\begin{array}{l}\text { Holding in } \\
\text { Crane }\end{array}$ & 1.19 & $100.00 \%$ \\
\hline
\end{tabular}

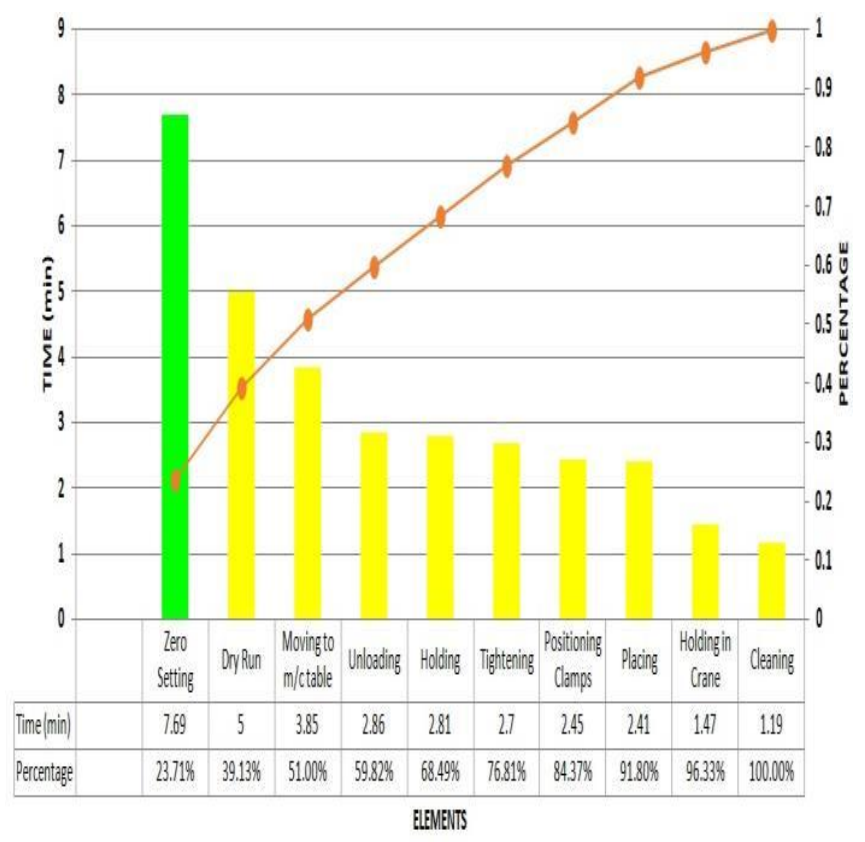

Fig. 4. Pareto Analysis

The main effect in the organization is found to be a changeover time. So root cause analysis is made for the changeover effect. And in results more than the expected sub causes were found and are listed in the Ishikawa diagram.

Essentially it is based on four general principles, extended throughout this article:

- Define and describe properly the event or problem (five why's technique).

- Establish a timeline from normal situation until the final crisis or failure.

- Distinguish between root causes and causal factor.

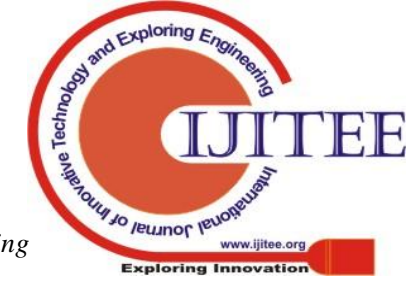




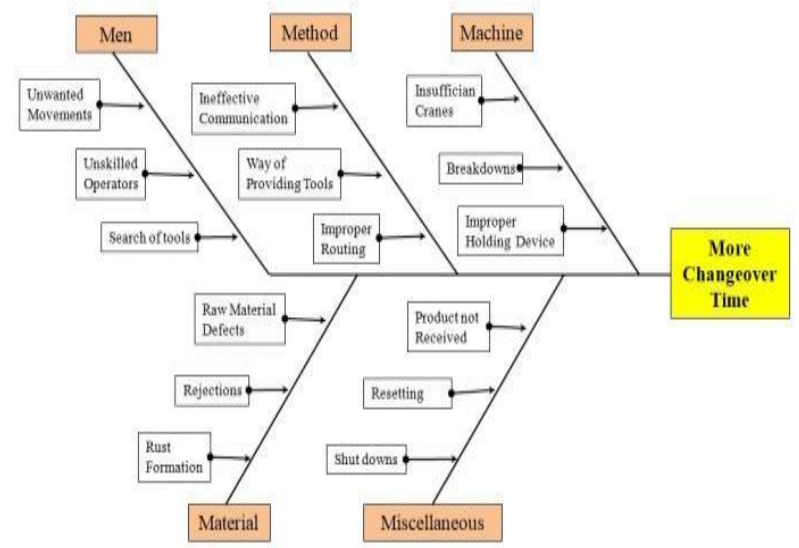

Fig. 5. Cause \& Effect Diagram

By the inference from Pareto analysis, it is clearly visible that zero setting is the parameter which consumes more time. If it is eliminated from the setup time, approximately 10 minutes is reduced from changeover time. So with this parameter holding and placing parameters are also taken into account for minimization. This is so because of inter relation between these parameters. To overcome these problems SMED is chosen because it is also considered as Poka-Yoke device here. To design a special quick changeover fixture some data are required. This has been collected from the survey of on- going processes.

Support components usually bear the brunt of the forces delivered during the operation. To reduce the chances of failure, support components are usually not also designed as clamps.

The corner L-block was the SMED and the clamping shown was vice clamp. With the help of data die is made at specific height $20 \mathrm{~mm}$ and the walls are made perpendicularly for the perfect placement of job in the die. Nicks are made at the corners for easy up the corner seating. The clamping used here was vice clamping to arrest other degrees of freedom. Finally only one z-axis movement is left and is also arrested by cutting process. After the implementation of SMED the changeover time is reduced to 21.74 minutes from 32.73 minutes, which means more than 10 minutes have been reduced from the changeover time which is $33.579 \%$ reduction from the existing setup.

Cost Analysis after SMED for a Machine:

Time taken for Setup (existing) $=32.73 \mathrm{~min}$

Time going to be saved in setup $=12.69 \mathrm{~min}$

Actual time after setup

$=32.73-12.69$

$=20.04 \mathrm{~min}$

Charge for production/hr

$=$ Rs. $1400 / \mathrm{hr}$

$=$ Rs. $24 / \mathrm{min}$

Job changeover done per shift

No. of shifts

Job changeover done per day

Time saved per day

Wages paid for labour (exp)

Total working days in month
Wage for labour/day

$=20000 / 24$

850(approx)

Cost of time saved

$=76.14 * 24$

Profit for single machine

$=$ Rs. 1827.36

Total no. of mould producing

Profit for 9 machines /day

$=9$ (VMC Machines)

$=1827.36 * 9$

$=$ Rs. 162246.24

Total working days/year

$=276$ days

$$
\begin{aligned}
\text { Profit for Vishal/ year } & =276 * 14210 \\
& =\text { Rs. } 45,39,165
\end{aligned}
$$

Comparison between before and after SMED:

Profit/ day= More than twice of labour charge

Profit/ year $=2 \%$ more than its actual turnover

Productivity gets improved about 5.34\%. On utilizing the SMED technique in work piece changeovers, the setup time is reduce from 32.73 minutes to 20.04 minutes. This leads to reduction in lead time of mould base production about 15 minutes. Thus it clearly shows the reduction of setup time about $33.578 \%$ approximately $34 \%$.

\section{CONCLUSION}

The various methods are used to optimize the time in different zones in a working place and increase the production of components for dispatch. By using some other lean tools more non-value adding activities are eliminated like tool reference in tool box, material transporting time, overproduction, inventory storage, etc. The Ranked Position Weighted Method is used to find the line efficiency and work stations for minimising the waste and idle time and increasing the efficiency. The transportation of product from one process to another process inside an industry by alternating the layout and reject the waste by implementing $5 \mathrm{~S}$ concept to optimise the time up to 200 seconds per component. In addition to that reduction of setup time by using additional fixture (from outsource) to save the setup time of about 12.69 minutes for each component. There must be used different methods to optimise the excess time for increasing the production and profit.

\section{REFERENCES}

1. M.Mohan Prasad, K.Ganesan, R.K.Suresh. “An Optimal Balancing Of Multiple Assembly Line For A Batch Production Unit” International Journal of Lean Thinking Volume-4, Issue-2, (December 2013)

2. Shamuvel VPandit, Sunil J Kadam, Avinash Kharat, Chetan U Nayakawade. "Productivity Improvement by Application of Line Balancing” International Journal of Innovative Research in Science, Engineering and Technology Vol. 3, Issue 4, April 2014.

3. Krantikumar B. Chavare, Prof. Abid M. Mulla. "Application of Ranked Position Weighted (RPW) Method for Assembly Line Balancing” International Journal for Research in Applied Science \& Engineering Technology (IJRASET), Volume 3 Issue VI, June 2015 ISSN: 2321-9653.

4. M.F.M.A.Hamzas, S.A.Bareduan, M.Z.Zakaria, S.Ghazali, and S.Zairi. Implementation of ranked positional weight method (RPWM) for double-sided assembly line balancing problems AIP Conference Proceedings 1885, 020183 (2017). 
5. Santosh T.Ghutukade, Dr.Suresh M.Sawant. "Use of ranked position weighted method for Assembly line balancing" International Journal of Advanced Engineering Research and Studies/II/IV/July-Sept., 2013/01-03

6. Siyu Chen, Shuhai Fan, Jiawei Xionga, Wenqian Zhanga. "The Design of JMP/SAP Based Six Sigma Management System and its Application in SMED” Procedia Engineering 174 (2017) 416 - 424.

7. R.Sundar, A.N.Balaji, R.M.SatheeshKumar. "A Review on Lean Manufacturing Implementation Techniques” Procedia Engineering 97 (2014) 1875-1885.

8. U.Dombrowski, D.Ebentreich, P.Krenke, "Impact analyses of lean production systems” Procedia CIRP57 (2016) 607 - 612.

9. Mohammed Viqar Nadaf Pinjar, Dr.Shivakumar S, Dr.G V Patil, "Productivity Improvement through Single Minute Exchange of Die (SMED) Technique” International Journal of Scientific and Research Publications, Volume 5, Issue 7, July 2015.

10. Chetan S Sethia, Prof. P. N. Shende, Swapnil S Dange. "A Case Study on Total Productive Maintenance in Rolling Mill” JETIR Volume-1, Issue-5.

11. Adanna.I.W, Prof.A.Shantharam "Improvement of Setup Time and Production Output with the use of Single Minute Exchange of Die Principles.(SMED)" International Journal of Engineering Research. Volume No. 2, Issue No. 4, pp : 274-277.

12. Anna Karwasz, Przemyslaw Chabowski, "Productivity increase through reduced changeover time" Journal of Machine Engineering, Vol. 16, No. 2, 2016.

13. Dorota Stadnicka, Dario Antonelli "Application of Value Stream Mapping and Possibilities of Manufacturing Processes Simulations in Automotive Industry" FME Transactions (2015) VOL. 43, No 4, 2015.

14. G.V. Nenov, T.Sz!ecsi. "Increasing CNC machine tool productivity by using tool-part touch control" Robotics and Computer Integrated Manufacturing 18 (2002) 291-296.

15. Janez Kusar, Tomaz Berlec, Ferdinand Zefran, Marko Starbek. "Reduction of Machine Setup Time" Journal of Mechanical Engineering 56(2010)12, 833-845.

16. M. S. Desai. "Productivity Enhancement by Reducing Setup Time SMED:Case study in the Automobile factory" Global Journal of Researches in Engineering Mechanical and Mechanics Engineering Volume 12 Issue 5 Version 1.0 2012.

17. J. Jaroszewicz, M. Baran, M. Grodzka, D. Humienna. "Reduction of changeover time in a CNC milling machine using erowa zeroing system based on the example of samasz company, biatystok" ZESZYTY NAUKOWE POLITECHNIKI ŚLĄSKIEJ 2017.

18. Mohd Norzaimi bin Che Ani, Mohd Sollahuddin Solihin Bin Shafei. "The Effectiveness of the Single Minute Exchange of Die (SMED) Technique for the Productivity Improvement" Applied Mechanics and Materials Vols. 465-466 (2014) pp 1144-1148.

19. Mr. Ajinkya Jadhav, Dr. N. R. Rajhans, Mr. Vinayak Angane. "Reduction In Overall Changeover Time In General Motors, India" National Conference on, Modeling, Optimization and Control, 4th -6th March 2015, NCMOC - 2015.

20. Shashikant Shinde, et al. "Set up time Reduction of a Manufacturing Line using SMED Technique" International Journal of Advance Industrial Engineering ISSN 2320 -5539.

\section{AUTHORS PROFILE}

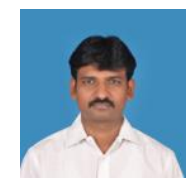

Dr. S. KARTHIKEYAN is working as Associate Professor in the Department of Automobile Engineering, Kalasalingam Academy of Education and Research, Virudhunagar District, Tamilnadu, India. He is currently doing active research in the area of Tribology of natural composite materials. His other areas of interest include characterization of materials and Supply Chain Management. 